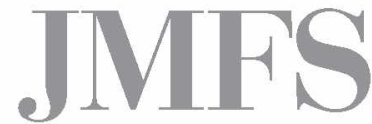

Journal of Management and Financial Sciences
Volume X

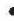

Issue 29 (September 2017)

pp. 185-193

Warsaw School of Economics

Collegium of Management and Finance

Joanna Dominowska

Collegium of Management and Finance

Warsaw School of Economics

\title{
Effectiveness of State Supervision and Control of Foundations' Economic Activity
}

ABSTRACT

The construction of supervision and control of foundations and their economic activity in Poland is fairly well developed. The main goal of this research was to ascertain whether the procedure of supervision works effectively. It was also to highlight those supervision elements and stages that do not perform their role accurately and to indicate the reasons thereof. It is important to intensify the discussion on the change of the model of foundation supervision into a more effective system on the one hand, and less troublesome for entrepreneurs on the other. The research of this type has never been conducted through the cross-impact analysis. Every ministry presents only the analysis in relation to the foundations subordinated to them. There is no pooled analysis of the supervision state on economic activity of foundations in Poland, and in this respect, this study is a novel scientific contribution. The conclusion drawn from it points to a necessity for simplification, standardisation (a uniform foundation activity report form is not sufficient) and the introduction of instruments to affect the current foundations' activity.

Keywords: state supervision, economic activity of foundation, starosts/ministry supervision, annual report, control

JEL Codes: K230, K400, H3 


\section{Introduction}

The construction of supervision and control over foundations' economic activity in Poland is fairly well developed. This research is to examine its effectiveness. It is also to highlight those elements which do not perform their role accurately, and the publication, as intended by the author, is to contribute to the discussion on the change of the model of supervision of foundations into a more effective system on the one hand, and less troublesome for entrepreneurs on the other. The research of this type has never been conducted through the cross-impact analysis. Every ministry presents only the research of foundations subordinated to them and even those are being done only partially. There is no integrated, complex analysis of the state supervision of foundations' economic activity in Poland, and in this respect, this study is a new scientific contribution. The aim of this study was also to highlight the non-efficient stages and tools of supervision. Because of the divided construction of the supervision - between ministers and courts, it was important which of the two organs lacks activity in that system.

\section{The Current State of Supervision and Control in Poland}

\section{Essential elements of the survey}

The research made use of the historical and comparative as well as dogmatic methods to describe the legal state, and the analytical and empirical methods to conduct a survey.

The first stage examined whether the foundations fulfilled their reporting obligations. In order to do this, the researcher surveyed appropriate ministry units and auxiliarily used statistical data available on the ministries' websites.

At first, it was examined how often the appointed institutions had used their authority in recent years (the survey referred to 2011 and 2012 as no data on 2013 were available). Primarily, it was examined:

1) whether the foundations met their obligation of annual reporting on their activity to the respective minister and whether the report followed the requirements defined in the Regulation on the framework scope of reports on the foundations' activities, in particular whether they included all the required information on the economic activities;

Additionally, the survey asked the following questions: 
2) whether a given minister audited the foundations in 2011 and 2012;

3) how often the respective ministers or starosts (local governors) apply to the court of law for the examination whether a given foundation operates in compliance with the law and the statute as well as its establishment objectives;

4) how often the respective ministers or starosts applied to the court of law for the repeal of a resolution made by the foundation management board and whether such applications resulted in the actual court verdict on repealing the foundation management board resolution;

5) how often the respective ministers or starosts addressed the foundation to remove irregularities in their management board activities or to effect changes in the foundation management board in due time;

6) how often the respective ministers or starosts applied to the court of law for the suspension of the foundation management board and the appointment of an official receiver and whether the court verdict was in line with the application.

The second stage of the survey examined whether the reports are subject to appropriate analyses in the respective ministries in the area of information about the economic activities conducted by foundations, and consequently whether the supervision is effective in its practical functioning. In this connection, it was examined whether there is an organisational unit in a ministry or at least one substantive employee dealing with the foundations' reports, and also whether or not and how often the above-mentioned supervision measures with regard to management boards are applied in relation to the reports or irrespective of them. It was also examined whether the supervision measures affecting the management boards have anything in common with the management boards' decisions on the foundation economic activities, in particular with the increased economic activity of the foundation, especially the economic activities on a large scale.

\section{Research results}

The ministers exercise supervision over 12,497 foundations. The number of foundations supervised by every minister is widely diversified.

The supervision over $70 \%$ of foundations is in the competencies of five ministers. These are: Minister of Culture and the National Heritage, Minister of Health, Minister of Labour and Social Policy, Minister of National Education and Minister of Environment.

The research was to indicate whether the supervision measures assigned to ministers are effective. For the most of the conducted survey, as well as the former research ${ }^{1}$

\footnotetext{
1 Cf. in particular Nadzór nad fundacjami (Foundations supervision), Warsazwa 2013.
} 
prove that a considerable number of foundations do not even fulfil the first stage of the supervision - that is the reporting duty (filling in the yearly report to the proper ministry).

There are a few reasons for that situation. Firstly, the obligation itself of publicising the reports should be formulated in a different, clearer way. It should simply be stated where exactly the report should be published. At present, it has to be sent to the proper ministry and published, without any clarification, when the requirement of publishing is met. Presently, it can be placed on foundations' websites, and made generally accessible in this way. The report made available in a foundation's headquarters is also regarded as published. Another obstacle to effective supervision is also the lack of deadline for the submission of the yearly report. Due to this, it has been assumed that a foundation may submit the report on its activity conducted in a calendar year by the end of the following year.

The default on report submission in due time or no information in the report indicating incorrect activities of a foundation should result in the response of the state administration supervisor. However, a serious hindrance is the practice of not updating information, e.g. on the change of the seat of a foundation or on board members in the National Court Register (KRS). It considerably obstructs the enforcement of fulfilment of foundations' reporting duties.

According to the survey, the ministers do not possess a comprehensive knowledge of the operations of foundations supervised by them. Only six ministers ordered their staff to prepare overall periodic information on the supervised foundations. The Minister of Sport and Tourism, Minister of Treasury, Minister of Infrastructure and Development, Minister of National Defence, Minister of Environment and Minister of Labour and Social Policy receive such reports.

The research confirms that the present legal regulations actually retain a fictional state supervision of foundations, and the lack of information hinders a real ministry supervision. Ministers demand the change of regulations. The presented proposals are not uniform, though. The Minister of Infrastructure and Development and the Minister of Regional Development suggest the repeal of supervision of ministries over foundations. They support this concept claiming that foundations are not included in the list of public finance sector entities and their missions often go beyond the competence of one minister. They also claim that treasury offices, labour inspection institutions, the prosecutor's office and courts of law can force all the foundations to obey the law.

The remaining ministers indicate the necessity for positive changes in the regulations on their supervision of foundations and giving them the tools which will allow for the real supervision of these physical persons. In particular, there is a strong need 
for the change in the rules of reporting information by foundations and introducing sanctions for neglecting the term for submitting the report.

\section{Supervision effectiveness}

The analysis of the survey carried out by the author and the results of examination conducted in the ministries commissioned by the Prime Minister's Office ${ }^{2}$, explicitly indicate how seldom the ministers implement a formalised and periodic assessment of operation of the subordinated and supervised entities. And if it is done, it refers to the operation of entities within the financial sector or is formulated on the basis of conclusions resulting from the conducted audits. Although 14 out of all 17 ministers stated that the responsible ministry units are obliged to present a formalised operational assessment of subordinated or supervised entities, the information actually refers to only a few entities or certain areas of their operation.

The lack of a formalised and complex assessment may impede the ministers' supervision duties. Such an assessment would be important with regard to the duty of submitting statements on the state of management control in the areas managed by ministers introduced in 2010. According to the Regulation of the Minister of Finance of 2 December on the pattern of statement on the state of management control, it is submitted for example on the basis of monitoring of the state of implementation of goals and tasks.

The organisation of supervision affects mutual relations between the supervisor and the supervisee, and in particular the practice of sharing information between these two. Twelve ministers claimed that they could always obtain all the necessary supervision data. Five ministers informed about the cases of the negation of supervisor's authority. The supervised entities explained the refusal to cooperate pointing to their independence and possession of the status of legal entity.

The lack of effectiveness in foundations' supervision is recognised also by the Supreme Audit Office (NIK). According to the Office, the organisation of office work results in the lack of information flow between departments responsible for different supervision areas. The problem becomes especially significant if the departments responsible for the substantive and financial supervision are in the divisions of different undersecretaries of state. It causes, among other things, a longer procedure of acceptance of documents referring to a given unit.

2 Analysis of selected areas of supervision operation in the government administration, Prime Minister's Office, Warszawa 2012. 
The results of research explicitly confirm that on average half of the foundations submit reports to the supervising ministries on time. The highest "reporting rate" is noted within the Ministry of Finance (75\%), the lowest within the State Treasury (13\%)

Characteristically, the number of foundations supervised by every ministry is really different: from several dozen up to several thousand entities. From among ministries responding to the survey at ngo.pl, the most foundations were supervised by: the Ministry of Health $(2,600)$ and Ministry of Labour and Social Policy $(2,457)$; the fewest foundations by ministries of Finance (40) and Treasury (46).

The highest "timely reporting rate" was noted by the Ministry of Finance. However, it supervises the fewest foundations. Documents were sent on time from 30 out of 40 supervised entities. The smallest number of timely reports (13\%) were sent to the Treasury Ministry, which has also very few subordinated foundations. In between these two poles there are reports to the Ministry of National Defence (63\% of foundations reported on time), Ministry of Agriculture and Rural Development (58\%), Ministry of National Education (57\%), Ministry of Regional Development (50\%), Ministry of Foreign Affairs (48\%), Ministry of Environment (47\%), Ministry of the Interior (38\%), Ministry of Transport, Construction and Maritime Economy (37\%), Ministry of Health (36\%), Ministry of Science and Higher Education (35\%), Ministry of Labour and Social Policy (27\%) and Ministry of Justice (26\%). The spokesman for the last admits frankly that in the group of 124 supervised foundations, 24 have not submitted a report even once since they were registered. The Ministry of Culture and the National Heritage does not have overall information about the 2011 reports, only that for 2010. The Ministry of Administration and Digitisation after the assignment from the Ministry of the Interior, "obtained" foundations to supervise; according to the list on the ministry's website there were 212 entities in $2014^{4}$.

The survey questions were left unanswered by the Ministry of Economy and the Ministry of Culture and the National Heritage. Admittedly, the Ministry of Sport and Tourism responded to the survey, but without declaring the number of supervised foundations.

In relation to the supervision and control of certain activities of foundations, i.e. business activities, theoretically the report construction according to the Regulation ensures its isolation from the statutory activities and clarity of classification with regard to incomes and costs of these activities. As already indicated, reports should include the following information on the economic activities: the scope of activity

\footnotetext{
3 http://wiadomosci.ngo.pl/strona/852460.html

${ }^{4} \mathrm{http} / / / \mathrm{mac}$.bip.gov.pl/rejestry/wykaz-fundacji-nadzorowanych-przez-ministra-administracji-i-cyfryzacji.html
} 
compliant with the entry in the National Court Register; achieved incomes together with sources; economic activities' financial result as well as the percentage relation of income achieved from economic activities to the other sources; costs incurred on economic activity, data on the number of people employed in the foundation according to the positions held and isolation of those dealing exclusively with economic activities. However, the Law on Foundations and the Minister's Regulation lack, and as shown in the research, so does the practice of ministries, systemised or actually any systems of practical implementation of supervisory activities. It is not clear for the ministers how often they can audit foundations and how many times they should ask them to make their reports complete by the data on the scope of economic activities, what supervision instruments to use when the reprimanded foundation keeps defaulting on its obligations. Apart from the ultimate measure in the form applying to the court of law for confirmation that a foundation operates against the legal regulations, which seems to be too strict for the lack of completion of certain data in the report or its incorrect completion, but there are no measures in between.

\section{Conclusion}

The study indicates that the Polish system of law does not include effective and fast supervision and control measures of economic activities conducted by foundations, and the supervision is inconsistent and ineffective. De lege ferenda, ministers should be equipped with tools allowing them to acquire current information on the supervised foundations. A rational deadline for the submission of an annual report on foundation activities should be fixed. The current deadline (until the end of the year following the one the report refers to) is too distant. It is not in favour of effective supervision as the information on what is happening in a foundation reaches the supervisor even with a yearly delay.

However, the Law on Foundations and the Minister's Regulation as well as the practice of ministries lack, as shown in the research, systemised or actually any systems of practical implementation of supervisory activities. It is not clear for the ministers how often they can audit foundations and how many times they should make them complete their reports by the data on the scope of economic activities, what supervision instruments to use when the reprimanded foundation keeps defaulting on its obligations. Besides, the ultimate measure in the form applying to the court of law for establishing the foundation is working against law regulations, which seems to be too strict for the lack of completion of certain data in the report or incorrect completion, but there are no measures in between. 
The research showed the necessity for the creation of uniform standards of supervision of foundations, including a uniform report form. The necessity for their development is emphasized by the ministers themselves, who identify them as an essential and desired support for the supervision activities.

Another problem indicated by the research is the lack of flow of information as foundations are not obliged to report on their resolutions to the supervisors immediately after making them. As a result, the supervisor does not know what is happening in the supervised foundation and cannot apply appropriate supervision measures at its disposal in due time.

The summary of the research presented remarks de lege ferenda concerning changes in the legal regulations on foundations' supervision, including the economic activities conducted by foundations. It was underlined that the introduction of obligatory submission of reports in the same form in all the ministries would facilitate the work of supervisors as well as supervisees. This role is not performed by the Regulation itself; it would be sufficient, though, to enclose the report form to it. The Regulation only gives information to be disclosed in the report without proposing a unified report form. The introduction of such a unified form in all the ministries could result in more efficient analyses of reports and more reliable assessment. It would optimise human resources efficiency and give rise to a better possibility of the analysis of data submitted by all the foundations. It would also create a uniform supervision standard in all the ministries, which, as indicated in the research, is missing at present.

Another advantage for the supervisors would be to introduce a mechanism of information exchange between courts of law (KRS) and ministries concerning the obligation of passing information on changes in the data within the National Court Register.

\section{Bibliography}

1. Analysis of selected areas of operation of supervision in government administration, Prime Minister's Office, Warszawa 2012.

2. Anheier H.L., Salamon L.M., The Non-Profit Sector in Comparative Perspective, [in:] W. Powell, R. Steinberg, The Non-Profit Sector. A Research Handbook, 2nd ed., Yale University Press, New Haven 1999.

3. Grzelońska U., Rola sektora non-profit w polskiej gospodarce (Role of the Non-Profit Sector in the Polish Economy), "Studia Ekonomiczne" 2011, no. 44.

4. Izdebski H., Fundacje i stowarzyszenia (Foundations and Associations), AJP Partners, Warszawa 1994. 
5. Kruczalak K., Niektóre zagadnienia polskiego prawa fundacyjnego (Polish foundation law. Selected issues), [in:] Bączyk M. (Ed.), Księga Pamiątkowa Ku Czci Profesora Leopolda Steckiego (Festschrift in Honour of Professor Leopold Stecki). TNOiK, Toruń. 1997.

6. Kuć D., Nadzór nad fundacjami (Supervison of Foundations), UW WPiA, Instytut Nauki o Państwie i Prawie, Warszawa 2013.

7. Pindyck R., Rubinfeld D., Microeconomics, Prentice Hall, London 2001.

8. Siciński A., Styl życia, kultura, wybór - szkice (Style of Life, Culture, Selection: Sketches), Księgarnia Wydawnicza IFiS PAN, Warszawa 2002.

9. Trzaskowski R., Działalność statutowa a dziatalność gospodarcza fundacji, prawo i praktyka (Statutory Activity versus Economic Activity of Foundations. Law and Practice), Oficyna Naukowa, Warszawa 2003. 